\title{
BMP-2 hatása a humán embrionális szájpadlásból származó mesenchymalis preosteoblast sejtek morfológiájára és proliferációjára
}

\author{
DR. HRUBI EDIT*, IMRE LÁSZLÓ**, DR. BACSÓ ZSOLT**, DR. BÍRÓ SÁNDOR***, DR. JENEI ATTILA**, DR. HEGEDÜS CSABA*
}

\begin{abstract}
Fogászati implantáció során a hiányzó fogat vagy fogakat „műgyökerek”, beültetésével pótoljuk. Az integráció folyamatának felgyorsítása érdekében az egyik legújabb törekvés bioaktív anyagokkal, növekedési faktorokkal segíteni az implantátum körül a csontképződést. Ilyen molekula az amerikai gyógyszer- és élelmiszerügyi hatóság (FDA) által is elfogadott növekedési faktor a Bone Morfogenic Protein 2 (BMP-2) is. A BMP-2 ilyen jellegű alkalmazását in vitro tesztelésre alkalmas sejtvonalakon vizsgálják. Egyike ezeknek az osteoblast progenitor jellegű humán embrionális szájpadlás mesenchyma (HEPM) sejtvonal. Kísérleteink során vizsgáltuk a BMP-2 homodimer fehérjék hatását HEPM sejtek morfológiájára valamint proliferációjára, rövid idejü, háromnapos kezelés után.

Eredményeink azt mutatták, hogy háromnapos kezelés hatására a BMP-2 koncentrációjának függvényében a kezelt sejtek hamarabb tapadtak le, de végleges morfológiájukban, valamint proliferációjukban nem volt különbség.

A kezelés idejét növelve azonban a sejtek osztódási képessége lecsökkent, ami utalhat a sejtek differenciációjára.
\end{abstract}

Kulcsszavak: HEPM, BMP-2, osteoblast irányú differenciáció, LSC.

\section{Bevezetés}

A foghiányok pótlásának legmodernebb módszere a fogászati implantáció, melynek során fogászati „mügyökerek” beültetésével pótoljuk a hiányzó fogat vagy fogakat. Az implantátum körüli csontintegráció folyamatának felgyorsítása érdekében az egyik legújabb törekvés bioaktív anyagokkal, növekedési faktorokkal segíteni a csontképződést. Ezek lehetnek extracelluláris mátrix fehérjék, például kollagén, kondroitin-szulfát [15, 18], sejt-sejt kölcsönhatásban szerepet játszó adhéziós molekulák, például integrinek [5, 11, 18], osteoblast progenitor sejtek differenciációját, valamint osteoblast sejtek proliferációját elősegítő növekedési faktorok, például BMP-2, BMP-7, parathyroid hormon (PTH) [8]. Ez utóbbiak közül az amerikai gyógyszer- és élelmiszerügyi hivatal (FDA) által is elfogadott, BMP-2 homodimer sebészeti beavatkozások után végzett csont regeneráció során használt növekedési faktor. A BMP fehérjék egy kivételtől eltekintve a TGF $\beta$ fehérjecsaládba tartoznak. A BMP1 az egyetlen, mely nem tartozik a TGF $\beta$ fehérjecsaládba, ez a fehérje a csont extracelluláris mátrixában megtalálható peptidáz, mely a M12A fehérjecsaládba tartozik. [2, 14]. A BMP fehérjék morfogénekként számos szerv kifejlődésében, morfogenezisében szerepet játszanak, például a velőléc (BMP4 és BMP7) [13], az arckoponya (BMP7, BMP4, BMP2) [13], a húgyhólyag (BMP2, BMP7) [4], a petefészek kialakulásában (BMP2, BMP4, BMP5, BMP6, BMP15 és GDF9) [10], valamint a fogfejlődésben (BMP2, BMP4, BMP7) [13, 19, 23]. Az embrionális és posztnatális fejlődés során a BMP-k, l-es és II-es típusú receptorokon keresztül (BMPRI és BMPRII) fejtik ki hatásukat. Eddig háromféle I-es és háromféle II-es típusú BMP receptort írtak le. A BMP ligand - BMPR receptorkötődés intracelluláris szignált indít, részben a SMAD, részben MAPK - PI3 - PKC szignál transzdukciós útvonalak aktiválásával [12, 13, 22]. A receptor aktivált SMAD (R-SMAD) C-terminálison történő foszforilációja lehetővé teszi a mediátor SMADdal (Co-SMAD: SMAD4) való asszociációt. A keletkező SMAD oligomer két R-SMAD-ból és egy Co-SMAD-ból álló trimer, ami ezután a sejtmagba transzportálódik, kötődik a kromatinhoz és transzkripciós faktorokkal együtt hatva szabályozzák a target gén expresszióját. A TGF- $\beta$ és BMP specifikus SMAD komplexek inhibitor SMAD (I-SMAD: SMAD 6, SMAD 7) expressziót indukálnak, melyek feed-back útján negatívan szabályozzák a szignalizáció időtartamát és erősségét. [12, 22] A BMP-k jelátviteli útvonala interakcióban van az FGF, Hedgehog és Wnt jelátviteli útvonalakkal és számos transzkripciós faktor expresszióját regulálják, például SOX9, Cbfa1 és Msx [23]. Transzportjukat, aktivációjukat és felszabadulásukat, valamint receptorhoz való kötődésüket BMP kötő fehérjék szabályozzák [20]. (1. ábra) 


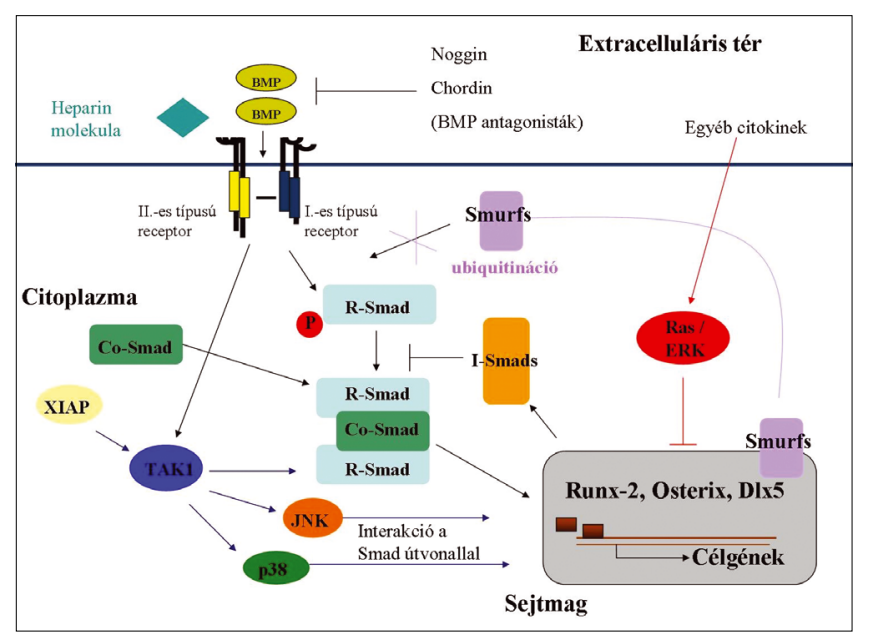

1. ábra: BMP szignáltranszdukciós útvonalak.

(Bessa PC, Casal M, Reis RL: Bone Morphogenetic Proteins in Tissue Engineering: the Road from Laboratory to Clinic, Part I /basic concepts/.

J. Tissue Eng. Regen. Med. 2008: 1-13.)

A kísérleteinkben használt BMP-2 a csontképződés során a differenciálódó osteoblastokban indukálja a Cbfa1 (Runx-2) gén expresszióját, amely transzkripciós faktorként kötődik további gének promótereihez, aktiválva azok expresszióját. Ilyen gének például az osteopontin, osteonectin, osteocalcin, kollagén I, csont szialoprotein, melyek differenciált osteoblast sejtekben termelődnek és szekretálódnak, kialakítva a csontszövet extracelluláris mátrixát, továbbá megkötik a kálciumot, illetve a hidroxiapatitot, így szerepet játszanak a csontszövet mineralizációjában.

Az irodalomban fellelhető adatok alapján a BMP-2 in vitro és in vivo is alkalmas csontfejlődés, valamint csontregeneráció indukálására, ezért klinikai alkalmazásában számos területen, így a fogászati implantációban is nagy lehetőségek rejlenek. A fogorvosi gyakorlatban alkalmazott titán bioaktív molekulákkal való módosításának legegyszerübb módja ezen molekuláknak a fém felszínen történő adszorpciója, ami történhet kezeletlen felszínen, felületi érdesítéssel porózussá tett titán felszínen [6, 7], vagy titán bevonására alkalmas porózus anyagok ( $\beta$-trikálcium-foszfát, hidroxiapatit) felszínén [1, 17]. Az adszorbcióval felvitt különböző molekulák a porozitás függvényében rövid idő alatt ( 3 nap) kidiffundálnak a környező szövetekbe [1, 6, 7, 17]. Ilyen módon a BMP-2 homodimer fogászati titán implantátumokon történő adszorpciója egy nagyon egyszerű és gyors módja lehetne a titánfelszín csontképződést elősegítő molekulával történő módosításának.

Célkitűzésünk ezért a BMP-2 homodimer fehérjével történő kezelés rövidtávú hatásainak vizsgálata humán embrionális szájpadlásból származó mesenchyma sejteken (HEPM). Ennek érdekében vizsgálni kívántuk BMP-2 homodimer fehérjék hatását a sejtek differenciációjára, hangsúlyozottan azok morfológiájára, valamint proliferációjára.

\section{Anyagok és módszerek}

\section{Sejtek tenyésztése}

HEPM (ATCC No.: CRL-1486) sejtek tenyésztése Eagleféle minimum esszenciális tápfolyadékban (EMEM) történt, kiegészítve 0,1 mM nem esszenciális aminosavakkal, 1mM Na-piruváttal, (ATCC: 30-2003), 10\% hő által inaktivált fötális borjúszérummal (FBS, Sigma Aldrich; F9665), 1\% L-glutaminnal (Sigma Aldrich; G3126) és 0,125\% gentamycinnel (Chinoin; 3587/01), standard tenyésztési körülmények között $37^{\circ} \mathrm{C}$ hőmérsékletü, $5 \%$-os $\mathrm{CO}_{2}$ és magas páratartalmú légkört biztosító inkubátorban tartott $25 \mathrm{~cm}^{2}$ területű szövettenyésztő flaskában.

\section{BMP-2 homodimer törzsoldat}

Az $1 \mathrm{mg}$ liofilizált BMP-2 homodimert feloldottuk (Antibodies-online $\mathrm{GmbH}$; Z00327) $1 \mathrm{ml}, 20 \mathrm{mM}$ steril ecetsav (Sigma Aldrich; 320099) 0,1\% borjúszérum albumin (BSA, Sigma Aldrich; A2153) oldatban, majd $10 \mu \mathrm{l}$-es aliquotokban tároltuk $-80^{\circ} \mathrm{C}$-on felhasználásig.

\section{Sejtek letapadásának és morfológiai változásának meghatározása}

72 órás, különböző koncentrációjú $(0,001 \mu \mathrm{g} / \mathrm{ml}, 0,01 \mu \mathrm{g} / \mathrm{ml}$, $0,1 \mu \mathrm{g} / \mathrm{ml}, 1 \mu \mathrm{g} / \mathrm{ml}$ ) BMP-2-vel (Antibodies-online $\mathrm{GmbH}$; Z00327), $25 \mathrm{~cm}^{2}$ területű sejttenyésztő flaskában történő kezelést követően, 0,05\%-os tripszin-etilén-diamin-tetraecetsav (tripszin-EDTA, Sigma Aldrich; T-4799) oldattal kezeltük a konfluens sejtkultúrát. EMEM tápfolyadékkal (ATCC: 30-2003) leállítottuk a tripszines emésztést, 5 perces 1200 rpm-en történő centrifugálást követően tápfolyadékban felvéve a sejteket Bürker-kamrával, fénymikroszkóp segítségével meghatároztuk a sejtek számát. 5000 sejtet helyeztünk nyolclyukú sejttenyésztő kamrába (Ibidi; 80826), megfelelő mennyiségú $(0,001 \mu \mathrm{g} / \mathrm{ml}$, $0,01 \mu \mathrm{g} / \mathrm{ml}, 0,1 \mu \mathrm{g} / \mathrm{ml}, 1 \mu \mathrm{g} / \mathrm{ml})$ BMP-2 homodimerrel (Antibodies-online $\mathrm{GmbH}$; Z00327) kiegészített tápfolyadékban. 4, 24 és 72 órán át $37^{\circ} \mathrm{C}-$-on inkubálva hagytuk a sejteket letapadni. Ezután $20 \mu \mathrm{g} / \mathrm{ml}$ fluoreszcein diacetát (FDA, Life Technologies; F1303) oldattal 30 percig jelöltük $37^{\circ} \mathrm{C}$-on a sejteket. Ezt követően háromszor mostuk tápfolyadékkal és lézer pásztázó citometriás módszerrel mértük a sejtek morfológiai paramétereit: kerület, terület, cirkularitás. Ezek közül az utóbbi faktor (melyet az előző kettőből számolhatunk) cirkularitás $=\left(\right.$ kerület $^{2} /$ terület $)$ jellemzi leginkább a sejtek alakját. Minél nagyobb ez a szám, a sejtek annál nyújtottabbak.

\section{Lézer pásztázó citometria (LSC)}

A citometriás méréseket iCys Laser Scanning Cytometerrel (CompuCyte) végeztük. Az FDA (Life Technologies; F1303) gerjesztéséhez argon-ion lézerrel generált $488 \mathrm{~nm}$ hullámhosszúságú fényt használtunk. A gerjesztés hatására emittált fluoreszcens fényt zöld csatornában 530 nm-en átengedő filteren keresztül detektáltuk. A morfológiai méréseket 20x nagyítású objektívvel normál scan módban, a proliferációs méréseket 10× na- 
gyítású objektívvel mozaik scan módban végeztük. A mérések és a kiértékelések iCys 3.4 szoftverrel történtek Windows XP operációs rendszer alatt futtatva.

\section{Sejtek proliferációjának mérése LSC-vel mért} összterület alapján

Steril körülmények között hatlyukú plate 1-1 well-jébe 20000 HEPM sejtet (ATCC No.: CRL-1486) helyeztünk középre csepegtetve. Egy kontroll és egy $1 \mu \mathrm{g} / \mathrm{ml}$ BMP-2vel (Antibodies-online $\mathrm{GmbH}$; Z00327) kezelt mintát vizsgáltunk. 3 napos $37^{\circ} \mathrm{C}$-on történő inkubálást követően $2 \mathrm{ml}$ EMEM medium (ATCC: 30-2003) és 0,5 ml $20 \mu \mathrm{g} / \mathrm{ml}$ FDA (Life Technologies; F1303) oldatban 30 percig jelöltük, majd mostuk a sejteket kétszer $3 \mathrm{ml}$ EMEM mediumban (ATCC: 30-2003) és LSC-vel mértük a sejtek összterületét. Mérés után a kezelt sejtekhez $3 \mu \mathrm{l}$ $1 \mathrm{mg} / \mathrm{ml}$ BMP-2-t (Antibodies-online $\mathrm{GmbH}$; Z00327) raktunk. 48 óránkét mértük a sejtek összterületét 9 napig nyomon követve, minden mérés után friss BMP-2 (Antibodies-online GmbH; Z00327) került a sejtekre, majd a BMP-2 (Antibodies-online GmbH; Z00327) kezelést abbahagyva további 8 napig vizsgáltuk a sejtek proliferációját.

\section{Alamar blue assay}

Steril körülmények között 96 lyukú plate 1-1 well-jébe 5000 HEPM sejtet (ATCC No.: CRL-1486) helyeztünk. 24 órás $5 \% \mathrm{Co}_{2}$-ban $37^{\circ} \mathrm{C}$-on történő inkubálás után a letapadást követően mostuk a sejteket színtelen EMEM (Sigma Aldrich; M4144) tápfolyadékkal, majd $100 \mu \mathrm{l}$, színtelen EMEM (Sigma Aldrich; M4144) tápfolyadékban 10x-re hígított Alamar blue reagenssel (Life Technologies; DAL 1100) történő 4 órás inkubációt követően Synergy HT plate reader (Bio Tek) készülékkel mértük a mintákat, fluoreszcens módban, $530 \mathrm{~nm}$ hullámhoszszúságú fénnyel gerjesztve, $590 \mathrm{~nm}$ hullámhosszon detektálva. Mérés után eltávolítottuk a redukált Alamar blue reagenst, majd különböző koncentrációjú $(0,001 \mu \mathrm{g} / \mathrm{ml}$, $0,01 \mu \mathrm{g} / \mathrm{ml}, 0,1 \mu \mathrm{g} / \mathrm{ml}, 1 \mu \mathrm{g} / \mathrm{ml}$ ) BMP-2-vel (Antibodiesonline $\mathrm{GmbH}$; Z00327) kiegészített friss EMEM mediumban (ATCC: 30-2003) inkubálva kétnaponta megismételtük a mérést.

\section{Immunfluoreszcens jelölés}

Készítettünk egy kezeletlen kontroll és egy $1 \mu \mathrm{g} / \mathrm{ml}$ BMP-2-t (Antibodies-online GmbH; Z00327) tartalmazó mintát. 24000 sejtet helyeztünk nyolclyukú sejttenyésztő kamra egy-egy well-jébe. Háromnapos $37^{\circ} \mathrm{C}$-on történő inkubálást követően mostuk a sejteket háromszor három percig foszfát-pufferelt fiziológiás sóoldattal (1× PBS, phosphate-buffered saline, Sigma Aldrich; PBS1), majd fixáltuk és permeabilizáltuk a mintákat két percig $200 \mu \mathrm{l}$ acetonnal (Sigma Aldrich; 650501). Ezt követően ismét mostuk a sejteket $1 \times$ PBS-ben (Sigma Aldrich; PBS1), majd jelöltük a mintákat harminc percig $4 \mu \mathrm{g} / \mathrm{ml}$ Fitc phalloidint (aktin filament-zöld) (Life Technologies; A12379), $20 \mu \mathrm{g} / \mathrm{ml}$ Propidium jodidot (sejtmag-piros) (Life Technologies; P3566), tartalmazó 1xPBS-sel (Sigma Aldrich;
PBS1), mely tartalmazott 1\% BSA-t (Sigma Aldrich; A2153). Mostuk a sejteket 5 mM-os EDTA-t tartalmazó PBS-sel. A mintákat $5 \mathrm{mM}$-os EDTA-t (Sigma Aldrich; E6758) tartalmazó $1 \times$ PBS (Sigma Aldrich; PBS1) és antifade (Life Technologies; P36930) elegyében tároltuk, majd konfokális mikroszkóppal készítettünk képet a mintákról.

\section{Konfokális mikroszkóp}

A mikroszkópos felvételeket Zeiss LSM510 típusú konfokális mikroszkóppal készítettük. A fluoreszceinnel jelölt falloidint (Life Technologies; A12379) $488 \mathrm{~nm}$ hullámhosszúságú, argon lézerrel előállított fénnyel gerjesztettük és az emittált fluoreszcens fényt BP500-530 filteren keresztül detektáltuk. A propidium jodidot (Life Technologies; P3566) 543 nm hullámhosszúságú, HeNe lézerrel előállított fénnyel gerjesztettük és az emittált fluoreszcens fényt BP560-615 filteren keresztül detektáltuk. A minták vizsgálatához C-Apochromat 40×/1,20 W Korr UV-VIS-IR objektívet alkalmaztunk.

\section{Statisztikai analízis}

Kapott eredményeink statisztikai elemzéséhez ANOVA-t és Bonferroni post hoc tesztet alkalmaztunk. Szignifikánsnak a $p<0,05$ különbséget tekintettük. Adatainkat átlag \pm SD (szórás) ábrázoltuk. Az ábrákon a csillaggal jelölt értékek a kontrollhoz viszonyított statisztikailag szignifikáns különbségeket jelölnek.

\section{Eredmények}

Kísérleteinkben a BMP-2 homodimer rövid távú hatását vizsgáltuk háromnapos (72 órás) kezelést követő morfológiai, valamint proliferációs vizsgálatokkal. A morfológiai mérések során három paramétert vizsgáltunk: terület, kerület, valamint cirkularitás. A nem letapadt HEPM sejtek morfológiája kerek, míg a már letapadt sejtek fibroblasthoz hasonló elnyújtott alakúak, hosszú nyúlványokat növesztenek, így a letapadás során mindhárom vizsgált paraméter megnő. (2. ábra) A méréshez elengedhetetlen, hogy a sejtek különálló módon helyezkedjenek el és ne konfluensen. A háromnapos BMP2 kezelést követően ezért a sejteket szétválasztottuk

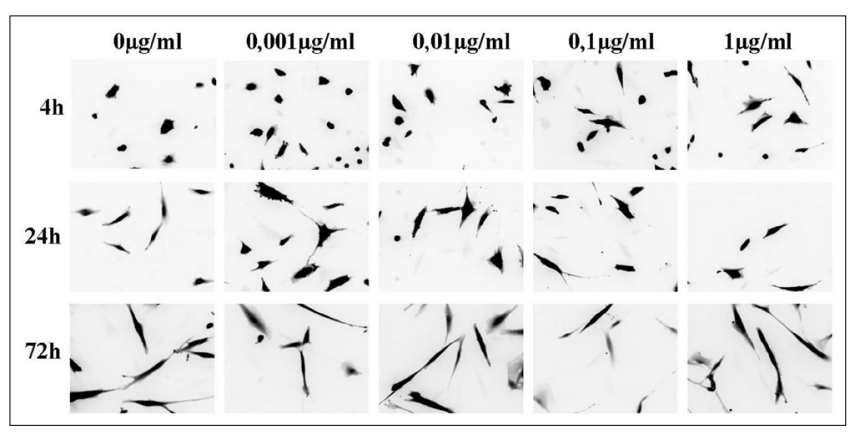

2. ábra: LSC-vel végzett morfológiai vizsgálat szkennelési területeiről készült

egy-egy reprezentatív mikroszkópos felvétel. 

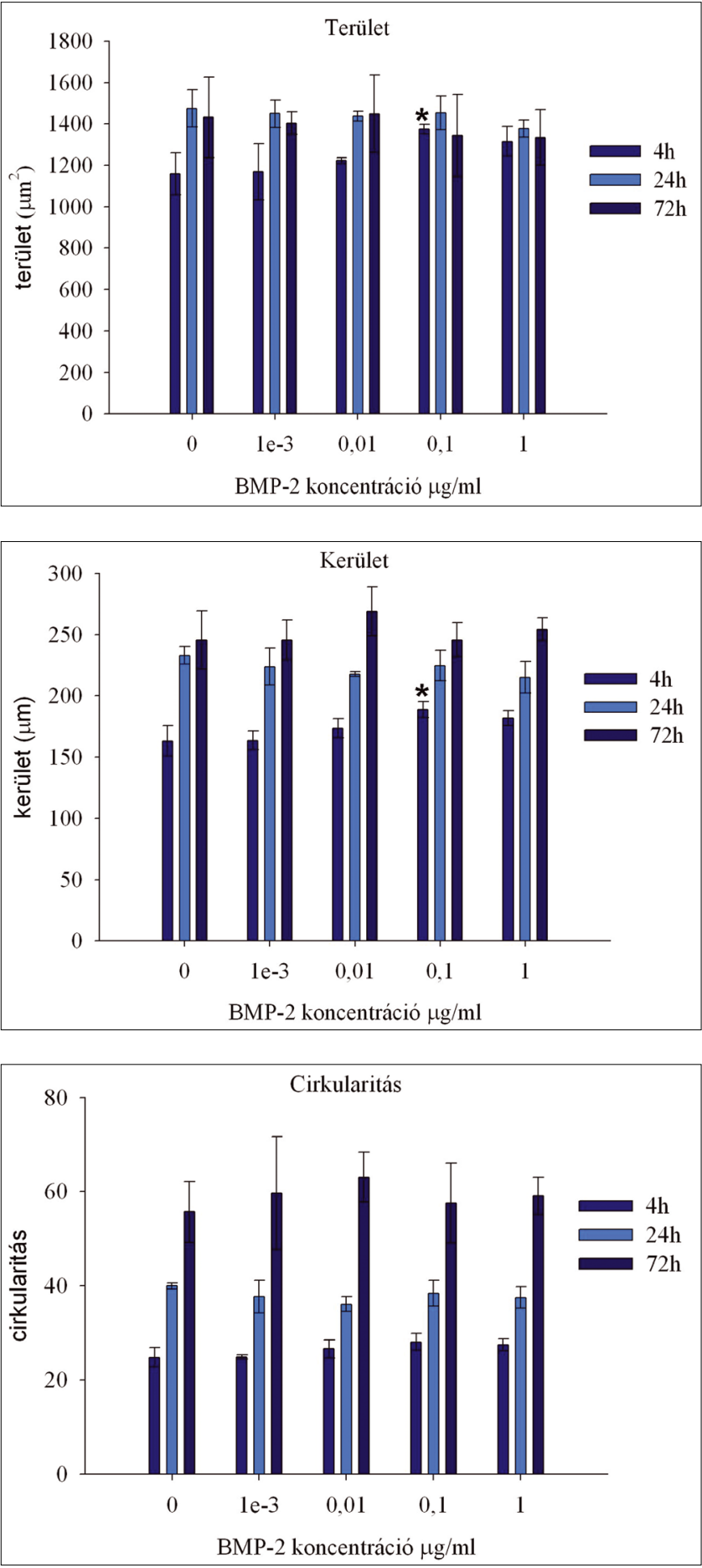

3. ábra: BMP-2 koncentrációsorral 72 óráig kezelt HEPM sejtek letapadásának és morfológiájának vizsgálata LSC-vel.

Az oszlopdiagramokon a három jellemző morfológiai paraméter három független kísérletben történt mérésének átlaga és szórása (SD) van ábrázolva: $(\mathrm{A})$ terület, $(\mathrm{B})$ kerület, $(\mathrm{C})$ cirkularitás.

egymástól és a felületről, és megfelelően kis koncentrációban, hogy citométerrel kontúrozni tudjuk az egyedi sejteket, újra letapasztottuk. A letapadás során továbbra is fenntartottuk a BMP-2 kezelést, valamint LSC-vel monitoroztuk a letapadási folyamat során változó sejtmorfológiát. 4 óra elteltével kezdeti letapadás volt ta- pasztalható, ahol a BMP-2 koncentrációjával korrelálva mindhárom morfológiai paraméter növekedést mutatott. Három független kísérletet elvégezve $0,1 \mu \mathrm{g} / \mathrm{ml}$ BMP-2 koncentrációnál a terület és kerület esetén a növekedés statisztikailag szignifikánsnak bizonyult (statisztikai tesztben számolt $p$ értékek: $p$ (terület) $=0,039 ; p$ (kerület) $=0,015)$, amiből arra következtethetünk, hogy a BMP-2-vel kezelt HEPM sejtek hamarabb kezdtek letapadni, mint a kezeletlen kontrollsejtek. 24, illetve 72 órás inkubációt követően a letapadás fokozatosan teljessé vált, a sejtek elérték végleges morfológiájukat, ahol cirkularitásuk, területük és kerületük nem mutatott különbséget. A teljes letapadást jelentő 72 óra elteltével minden BMP-2 koncentrációnál hasonló értékeket mértünk mindhárom paraméter esetén, ezért azt a következtetést vontuk le, hogy a BMP-2 kezelés nem volt hatással a sejtek végleges morfológiájára. (3. ábra) További kísérletben konfluens sejtkultúrában is megvizsgáltuk a sejtek morfológiáját a legnagyobb, $1 \mu \mathrm{g} / \mathrm{ml}$ BMP-2 koncentrációnál. Háromnapos kezelést követően a közvetlenül a sejtmembrán alatt lokalizálódó aktin filamentumok direkt fluoreszcens jelölésével láthatóvá téve a sejtek alakját, konfokális mikroszkóppal hasonlítottuk össze a kontroll és kezelt sejteket. Az előzőekhez hasonlóan nem találtunk különbséget a sejtek morfológiájában. (4. ábra)

A proliferáció vizsgálatához két módszert alkalmaztunk. Az egyik módszer egy általánosan alkalmazott, úgynevezett Alamar blue assay, ami az élő sejtek mitokondriumában lejátszódó redukciós reakción alapul, a másik egy lézer pásztázó citometián alapuló saját metodika. Ez utóbbi esetben a sejteket úgy helyeztük a sejttenyésztő plate-be, hogy azok együtt maradjanak egy foltban, majd a letapadást követően ennek a foltnak a nagyságát monitoroztuk LSC-vel több napon keresztül, FDA festéssel téve láthatóvá az élő sejteket. Az összterület meghatározása az LSC szoftverével történt, amely minden olyan eseményt körbekontúroz, amely-

FITC - Falloidin (F-aktin)
Propidium - jodid (sejtmag)
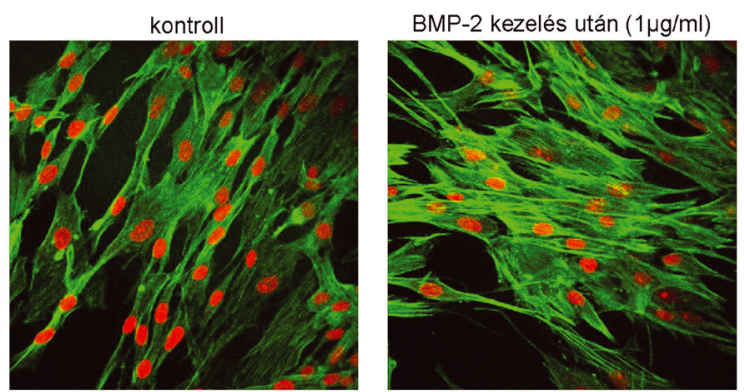

4. ábra: HEPM sejtek morfológiája Fitc-falloidin (aktin filament-zöld) és propidium jodid (sejtmag-piros) jelölést követően, konfokális mikroszkóppal vizsgálva. A bal oldali képen kezeletlen sejtek,

a jobb oldali képen az $1 \mu \mathrm{g} / \mathrm{ml}$ BMP-2-vel kezelt sejtek morfológiája látható. A sejtmembrán alatt lokalizálódó aktin filamentumok követik a sejt alakját, ami nem változott a BMP-2 kezelés hatására. 

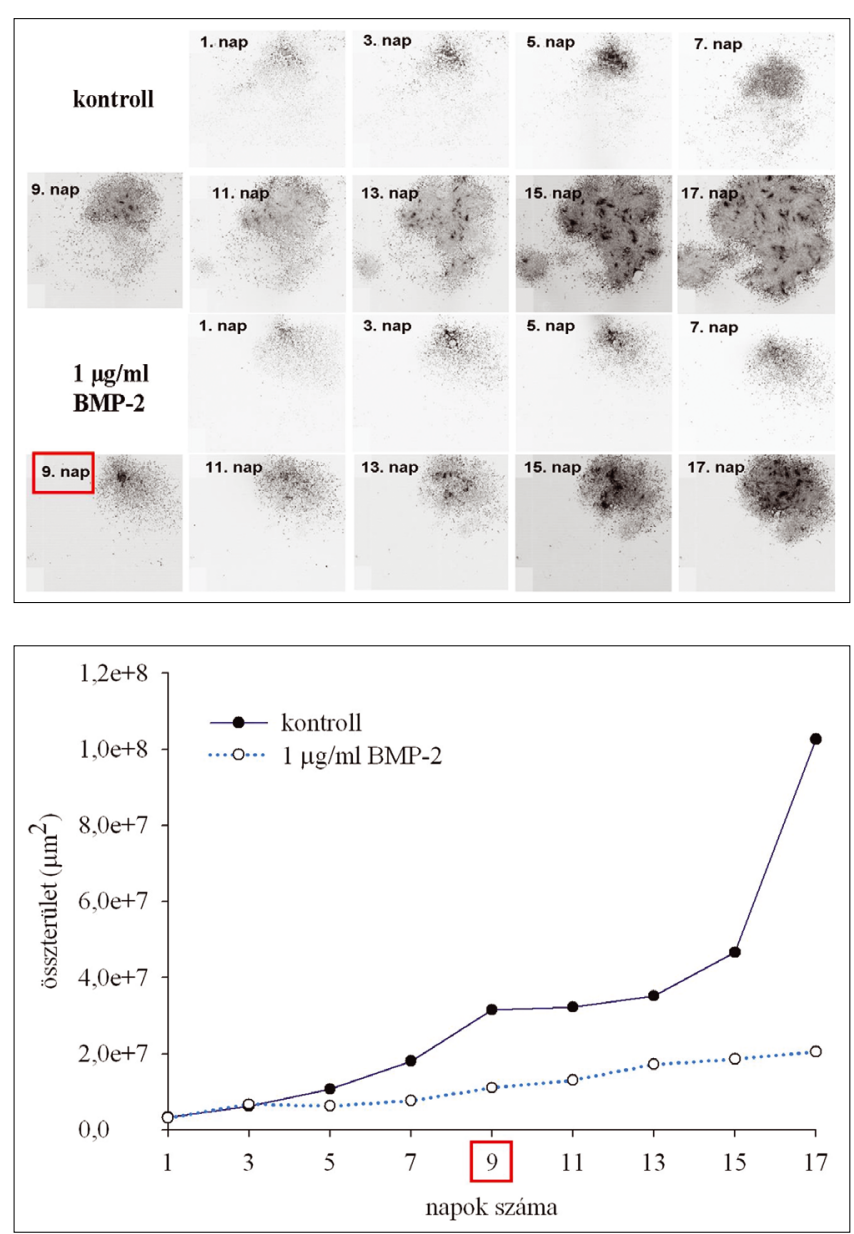

5. ábra: HEPM sejtek proliferációjának változása BMP-2 hatására LSC-vel vizsgálva, egy reprezentatív mérés eredményén bemutatva.

(A) Mosaic scan módban mért teljes szkennelési területek mikroszkópos képei. (B) $1 \mu \mathrm{g} / \mathrm{ml}$ BMP-2-vel kezelt, illetve kezeletlen sejtcsoportok összterületének változása a napok számának függvényében.

Kilenc nap elteltével a BMP-2 kezelést abbahagytuk.

nek fluoreszcenciája nagyobb a háttérértéknél, ebben az esetben a morfológiai méréstől eltérő módon nem a különálló sejteket, hanem az összeérő sejtek csoportját. A kísérletek során azt tapasztaltuk, hogy három nap elteltével a BMP-2 kezelésnek nem volt hatása, azonban hosszú távon, több mint egy hét elteltével a HEPM sejtek osztódására koncentrációfüggő módon gátló hatással volt a BMP-2. Az LSC mérés során a kezelt sejtekre a 9. naptól kezdve nem került BMP, de az osztódásuk tendenciájában ennek hatására sem jött létre változás. (5. ábra)

Az LSC módszerrel kapott eredményt validáltuk egy általánosan használt proliferációs assay-vel, amely az Alamar blue festék mitokondriumban történő redukciója következtében kialakuló színreakción alapul, melyet fluoreszcens módszerrel kvantifikálhatunk. Az eredmények megerősítették, hogy a BMP-2 homodimer koncentrációfüggő módon gátolta a sejtek proliferációját, ami a harmadik napon még nem volt megfigyelhető, az ötödik naptól kezdődően azonban a legnagyobb BMP-2

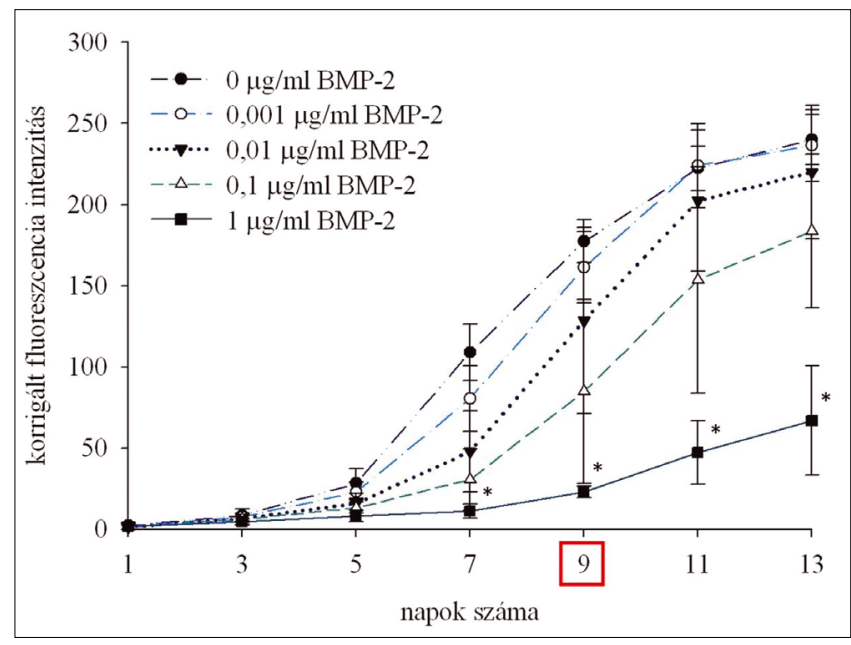

6. ábra: HEPM sejtek proliferációjának változása BMP-2 koncentráció sor hatására Alamar blue assay-vel vizsgálva. Az y tengelyen a háttérrel korrigált fluoreszcencia értékeket ábrázoltuk, a hibasávok három párhuzamos mérés szórását (SD) mutatják.

koncentrációval kezelt sejtek esetén a kísérlet végéig fennállt, illetve a sejtosztódás mértékében bekövetkezett csökkenés statisztikailag szignifikánsnak bizonyult. (Statisztikai tesztben számolt $p$ értékek: $p(5$. nap) $=$ 0,$011 ; p(7$. nap $) \leq 0,001 ; p(9$. nap $)=0,002 ; p(11$. nap $)=$ $0,001 ; p(13 . n a p) \leq 0,001)$ (6. ábra).

\section{Megbeszélés}

Eredményeink alapján háromnapos BMP-2 kezelés hatására a sejtek gyorsabb letapadása volt megfigyelhető, azonban a morfológiában, illetve a proliferáció mértékében nem tapasztaltunk változást. Irodalmi adatok alapján a HEPM sejtek differenciációját jelentősen befolyásolhatja a sejtkultúra dimenziója. Az általánosan használt 2D sejtkultúrával ellentétben kimutatták, hogy 3D sejtkultúrában növesztve a HEPM sejteket, már a harmadik naptól kezdve differenciációra utaló molekuláris változásokat tapasztaltak, például endogén BMP-2 termelés növekedése [16]. Ez alapján az általunk kapott eredmény a 2D felületen történő sejttenyésztésnek is lehet a következménye.

Proliferációs vizsgálatainkat meghosszabbítva egy hét után jelentős csökkenést tapasztaltunk a sejtosztódás mértékében, ami a BMP-2 kezelést abbahagyva is megmaradt. A proliferációban tapasztalt változás a legnagyobb $1 \mu \mathrm{g} / \mathrm{ml}$ BMP-2 koncentrációnál, az ötödik naptól kezdve statisztikailag szignifikánsnak bizonyult. Ezen megfigyeléseink összhangban állnak az irodalomban fellelhetô adatokkal, amelyekben leírták, hogy a BMP-2 sejttípustól függő módon valóban gátolja a sejtosztódást [3, 9, 21]. Ezek alapján a BMP-2 homodimernek volt hatása a HEPM sejtekre, ami bizonyítja, hogy a kí sérletekben használt fehérje funkcióképes volt, így a rövid időtartamú, háromnapos kezelés után kapott ered- 
mény nem a fehérje hibás voltának következménye. Morfológiai és proliferációs méréseink alapján azt a következtetést vonhatjuk le, hogy az adszorbeált BMP-2 deszorpciójának irodalmi adatok alapján feltételezett időtartama [1, 6] in vitro nem elegendő HEPM preosteoblast sejtek osteogén irányú differenciációjának elindításához, azonban a proliferációs kísérlet teljes időtartama alatt tapasztalt sejtosztódásbeli csökkenés arra utalhat, hogy egy hét után differenciálódási folyamat kezdődött el. Annak igazolására, hogy legalább egyhetes BMP-2 kezelés elősegíti az általunk használt osteoblast progenitor sejtvonal differenciációját osteogén irányba, olyan marker gének expressziós vizsgálatára lesz szükség, melyek az osteoblastok differenciációja során aktiválódnak, például Runx-2, BMP-2, osteocalcin, osteonectin, osteopontin, alkalikus foszfatáz.

A célkitűzésünkben leírt vizsgálati módszerekkel kapott eredményeink azt mutatják, hogy a vizsgált rövid időszak alatt sejt szinten nem figyelhetők meg preosteoblast sejtek differenciációjára utaló jelek.

Vizsgálataink alapján valószínűsíthető, hogy egy olyan egyszerü módszer, amely felületi adszorpción alapul, és gyors hatóanyag kibocsájtást tesz lehetővé, nem lenne eredményes a BMP-2 fogászati alkalmazására. A csontképződés hatékony elősegítését olyan hatóanyag leadó rendszer biztosíthatja, mely ellenáll az implantáció során fellépő mechanikai hatásoknak, valamint hosszú időn keresztül, azonos koncentrációban képes BMP-2 molekulák kibocsájtására.

\section{Köszönetnyilvánítás}

A kutatás a TÁMOP-4.2.2.A-11/1/KONV-2012-0036, valamint a TÁMOP 4.2.4.A/2-11-1-2012-0001 azonosító számú Nemzeti Kiválóság Program-Intelligens funkcionális anyagok: mechanikai, termikus, elektromágneses, optikai tulajdonságaik és alkalmazásaik címú kiemelt projekt keretében zajlott. A projekt az Európai Unió támogatásával, az Európai Szociális Alap társfinanszírozásával valósul meg.

\section{Irodalom}

1. Autefage H, Briand-Mésange F, Cazalbou S, Drouet C, Fourmy D, GoncalvÉs S, ET AL: Adsorption and Release of BMP-2 on Nanocrystalline Apatite-Coated and Uncoated Hydroxyapatite / $\beta$-Tricalcium Phosphate Porous Ceramics. Journal of Biomedical Materials Research Part B 2009: 706-715.
2. Bessa PC, Casal M, Reis RL: Bone morphogenetic proteins in tissue engineering: the road from laboratory to clinic, part II (BMP delivery). J Tissue Eng Regen Med 2008: 81-96.

3. Chen A., Wang D., Liu X., He S., Yu Z., Wang J: Inhibitory effect of BMP-2 on the proliferation of breast cancer cells. Mol. Med. Rep. 2012: 625-620.

4. DAVIES J: Intracellular and extracellular regulation of ureteric bud morphogenesis. J Anat 2001: 257-264.

5. Green PM, Ludbrook SB, Miller DD, Horgan CMT, Barry ST: Structural elements of the osteopontin SVVYGLR motif important for the interaction with alpha(4) integrins. FEBS Lett 2001: 75-79.6. Hall J, Sorensen RG, Wozney JM, WiKesJö UME: Bone formation at rhBMP-2-coated titanium implants in the rat ectopic model. J. Clin Periodontol 2007; 34: 444-451.

7. Keтавсhi A, Komm K, Miles-Rossouw M, Cassani DaD, Variola F: Nanoporous Titanium surfaces for Sustained Elution of Proteins and Antibiotics. Plos One 2014

8. Khosla SJ, Westendorf J, Oursler MJ: Building bone to reverse osteoporosis and repair fractures. J Clin Invest 2008: 421428.

9. Kim HK, Oxendine I, Kamiya N: High-contrentration of BMP-2 reduces cell proliferation and increases apoptosis via DKK1 and SOST in human primary periosteal cells. Bone 2013: 141-50.

10. KNIGHT PG, GLISTeR C: TGF-beta superfamily members and ovarian follicle development. Reproduction 2006: 191-206.

11. Mante FK, Little K, Mante MO, Rawle C, Baran GR: Oxidation of titanium, RGD peptide attachment, and matrix mineralization rat bone marrow stromal cells. J Oral Implantol 2004: 343-349.

12. Moustakas A, Souchelnytsky S, Heldin $\mathrm{CH}$ : Smad regulation in TGF-beta signal transduction. J Cell Sci 2001: 4359-4369.

13. Nie X, LuUkKo K, Kettunen P: BMP signalling in craniofacial development. Int J Dev Biol 2006: 511-521.

14. Rawlings ND, SalveSEN G: Handbook of proteolytic Enzymes ISBN: 978-0-12-382219-2

15. SCHLiepHAKE H: Application of bone growth factors - the potential of different carrier systems. Oral Maxillofac Surg 2010: 17-22.

16. Schneider GB, Boehrs JK, Hoopes JV, Seabold DA: Use of 3-dimensional environments to engineer osseous-like tissue. J. Dev. Biol. Tissue Eng 2011: 42-47.

17. Seidenstuecker M, Mrestani $Y$, Neubert RHH, Bernstein A, Mayr HO: Release Kinetics and Antibacterial Efficacy of Microporous $\beta$-TCP Coatings. Journal of Nanomaterials 2013

18. SheKARAN A, Garcia AJ: Extracellular matrix-mimetic adhesive biomaterials for bone repair. J Biomed Mater Res A 2012: 261272.

19. ThESLEFF I: Epithelial-mesenchymal signalling regulating tooth morphogenesis. J Cell Sci 2003: 1647-1648.

20. Umulis D, O'CoNnOR MB, BLAIR SS: The extracellular regulation of bone morphogenetic protein signaling. Development 2009: 3715-3728.

21. Wen XZ., Miyake S., Akiyama Y., Yuasa Y: BMP-2 modulates the proliferation and differentation of normal and cancerous gastric cells. Biochem. Biophys. Res. Commun. 2004: 100-6.

22. Wharton K, Derynck R: TGFbeta family signaling: novel insights in development and disease. Development 2009: 3691-3697.

23. Yamaguch A, Komori T, Suda T: Regulation of osteoblast differentiation mediated by bone morphogenetic proteins, hedgehogs, and Cbfa1. Endocr Rev 2000: 393-411. 
Hrubi E, ImRe L, Bacsó Zs, Bíró S, Jenei A, Hegedüs Cs

Effect of BMP-2 treatment on the morphology and proliferation of human embryonic palatal derived mesenchymal preosteoblast cells

In dental implantation missing tooth or teeth are replaced by artificial root. To reduce the time required for the integration newest trends are the enhancement of bone formation around the implant by bioactive molecules, growth factors. Such a molecule is bone morphogenetic protein - 2 (BMP-2) accepted by US Food and Drug Administration (FDA).

In these kind of applications effect of BMP-2 is tested in vitro on appropriate cell lines. One of these cell lines is the osteoblast like human embrionic palatal mesenchymal cell line (HEPM). In our experiments the effect of BMP-2 homodimer treatment was investigated on the differentiation of HEPM cells to osteoblasts reflected by changes in morphology, and proliferation after a short, 3 days BMP-2 treatment.

Results were showed that after three days BMP-2 treatment facilitates cell attachment on a concentration dependent manner however changes in cell morphology and proliferation could not be observed.

Continuing the BMP-2 treatment inhibitory effect was measured in cell proliferation, which may refer to cell differentiation.

Key words: HEPM, BMP-2, osteogen differentiation, LSC.

\section{Pályázat \\ Körmöczi-pályadíjra}

Felhívjuk minden, a Fogorvosi Szemlében publikáló,

35 évnél fiatalabb első szerzős cikk szerzőjét,

hogy pályázzanak a 2015. évi Körmöczi-pályadijira.

Pályázni csak a Fogorvosi Szemlében 2015-ben megjelent közleményekkel lehet. Kérjük, a közlemény különlenyomatának egy példányát mellékelje a pályázathoz.

A pályázat beadási határideje:

2015. október 15.

A pályázatokat, kérem, postán juttassák el címemre.

Dr. Tóth Zsuzsanna

az MFE főtitkára

SE Konzerváló Fogászati Klinika

1088 Budapest, Szentkirályi u. 47. 